\title{
THE INFLUENCE OF TENSILE MODULUS OF MEMBRANE MATERIAL ON MEMBRANE DEFLECTIONS UNDER POINT LOAD
}

\author{
A B S T R A C T
}

The properties of membrane structures are mostly defined by characteristics of the membrane material. One of the most important characteristics of membrane material is its tensile modulus. This paper presents a research about the relation of the tensile modulus of membrane material and membrane deflections under point load. The research was conducted on numerical models in specialised software. The value of the tensile modulus of the membrane material was varied and deflections under point load were recorded. Additionally, the orientation of the membrane material was altered and the type of membrane edges was changed. The obtained results helped better understanding of the influence of tensile modulus of the material on membrane deflections under point load.

\section{Vuk Milošević}




\section{INTRODUCTION}

Membrane structures are lightweight tensile structures that are much different from the "traditional" structural systems. Their specific properties are mostly caused by the unique properties of the membrane structural material. This material is very thin, only about $1 \mathrm{~mm}$, and has negligible compression and bending stiffness. Thus, in order to be stable, it has to be under tension. Consequently, membrane structures have to be in constant tension. To achieve this, special forms that are usually not present in other structural systems have to be designed for membrane structures. These forms are always double curved, and have negative Gaussian curvature in cases when they are mechanically prestressed, or positive Gaussian curvature when they are pneumatically prestressed. Even though the form of the membrane structures is a structural necessity, it has had a great impact on the increase of popularity of this system, since it is considered to be very attractive. Low thickness of the membrane material also has an important influence on the properties of membrane structures. On the positive side, the self weight of the membrane structures is extremely low and measures only a few kilograms per square metre. However, on the negative side, thermal properties of these structures are very poor, so they are often used to cover open spaces. Membrane material is also very flexible. This results in large deflections under external loads. Even though there are no strict limits for deflections of membrane structures, the clash between the membrane and other surfaces must be avoided to protect the membrane from damaging. The deflections of the membrane under external loads are dependent on the tensile modulus of the membrane material. In addition to this, tensile modulus is one of the most important properties of the membrane material. However, the influence of the tensile modulus of the membrane material on deflections under point load was not previously researched.

Researches about the tensile modulus of the membrane material have already been published. Uhlemann's doctoral thesis "Elastic constants of architectural fabrics for design purposes" presents a valuable research on the tensile modulus and Poisson's ratio of membrane materials. He states that there are two ways of modelling the behavior of a coated woven fabric: phenomenological modelling and microstructural modelling. In practical engineering of membrane structures, phenomenological modelling is used. It can further be combined with three different constitutive laws: linear-elastic, multilinear-elastic and nonlinear. The behaviour of membrane material is usually modelled by an orthotropic linear-elastic constitutive law, using elastic constants in the main anisotropic directions of the fabric. The stiffness of the material is of great importance for the structural analysis results. ${ }^{2}$ American standard about design of membrane structures defines a procedure for determination of tensile modulus (ASCE 
2010). Membrane Structures Association of Japan has published its procedures for testing of membrane material (MSAJ 1995). European Design Guide for Tensile Surface Structures also defines this process. ${ }^{3}$ Prospect for European Guidance for the Structural Design of Tensile Membrane Structures explores testing methods of membrane materials. ${ }^{4}$ The differences between different testing methods are also investigated. ${ }^{5}$ There are some published tests of specific membrane materials. ${ }^{6}$ At the European level, the work is underway to standardise the interpretation of membrane material test data. ${ }^{7}$ Research about the deflections under area load depending on the value of tensile modulus was also published by Bridgens and Birchall. ${ }^{8}$ Serbian researchers also investigated the dependence of membrane deflections on the position and intensity of point load and the effects of point load actions to membrane structures (see bibliography).

The research presented in this paper investigates the influence of tensile modulus on the deflections of membrane structures under point loads. This research is a part of the wider research about the effects of point load actions on membrane structures conducted at the Faculty of Civil Engineering and Architecture, University of Niš. To investigate the influence of tensile modulus on deflections of membrane structures, numerical models were created in specialised software and loaded with point loads. The value of the tensile modulus was varied and the resulting deflections were monitored. This process was repeated with different intensities of point loads. Two different orientations of the membrane material and two different boundary conditions were analysed in order to get a larger spectrum of results. More than 250 different sets of parameters on these

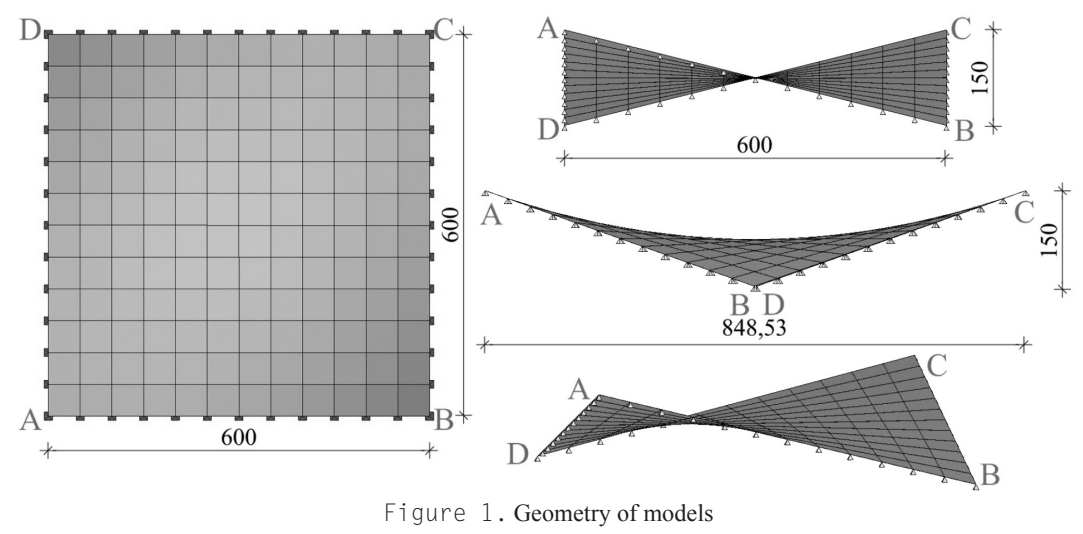


models were analysed. Based on the results obtained, the conclusions about the dependence of membrane deflection under point load on the value of the tensile modulus were drawn.

\section{METHODS}

The research was conducted on numerical models of membrane structures created in software Sofistik 2016. ${ }^{9}$ This software was already used in research of membrane deflections, e.g. by Tanev. ${ }^{10}$ The models are saddle shaped, have a square $6 \times 6 \mathrm{~m}$ base and are $1.5 \mathrm{~m}$ high. The thickness of the membrane is $1 \mathrm{~mm}$. Shear modulus is $25 \mathrm{kN} / \mathrm{m}$ and Poisson's ratio is 0.3 . The membrane is divided into 144 finite elements. Form-finding was done using modified force density method implemented in the used software. Prestress of the membrane was set at $3 \mathrm{kN} / \mathrm{m}$ in both principal directions. Point load was applied in the center of the membrane. Geometry of models is presented in Figure 1.

The tensile modulus of the membrane material was varied in the research and the maximal deflections under point load were recorded. In order to gain better understanding of the influence of tensile modulus on membrane deflections, two other parametres of the structure were varied too. At first, membrane edges were modelled as rigid and the membrane material is oriented diagonally. Afterwards, cases with flexible membrane edges and the parallel orientation were modelled too. Models with flexible edges have a cable prestress force of $30 \mathrm{kN}$. Four possible combinations of parametres are shown on models in Figure 2. For each model, form-finding was done separately. In addition, the intensity of the point load was varied from 0.1 to $1.0 \mathrm{kN}$ on all analysed models.

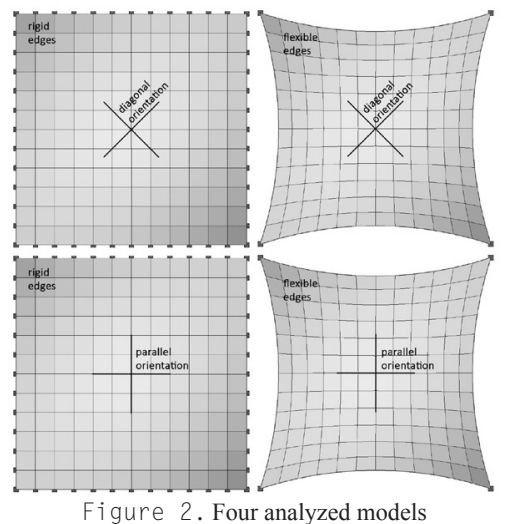




\section{RESULTS AND DISCUSSION}

A paper "Form and Function: The Significance of Material Properties in the Design of Tensile Fabric Structures" published in Engineering Structures by Bridgens and Birchall was taken as a starting point for this research. In this paper, the authors analyse membrane deflections under area load while varying the tensile modulus of the membrane material. Selected values of the tensile modulus in the mentioned research are 100, 300, 600, 1000, 2000 and 5000 $\mathrm{kN} / \mathrm{m}$. The range of the values is selected so it covers most of the membrane materials used today, and is therefore justified. However, it remained unclear how the exact values within this range were selected. For the research of influence of tensile modulus on membrane deflections under point load, the same range of values was selected for tensile modulus. However, it was decided that a check needs to be done, in order to choose which the most suitable values for analysis within this range are.

A model of the membrane structure with rigid edges and diagonal material orientation was loaded with a point load of $1 \mathrm{kN}$. On this model, the value of the tensile modulus was varied from 100 to $5000 \mathrm{kN} / \mathrm{m}$ with a step of $100 \mathrm{kN} / \mathrm{m}$. The tensile modulus of the material was the same in both principal directions. In such way, 50 different results for the maximum deflections under the applied point load were obtained. These results show the dependence of the maximum deflections on the value of the tensile modulus of the membrane material. It is already known that the maximal deflections of the membrane occur at the position in which point load acts. The results are shown in Figure 3 using continuous line. In the same Figure, the results that would be obtained by analysing six values chosen by Bridgens and Birchall are marked using dashed line.

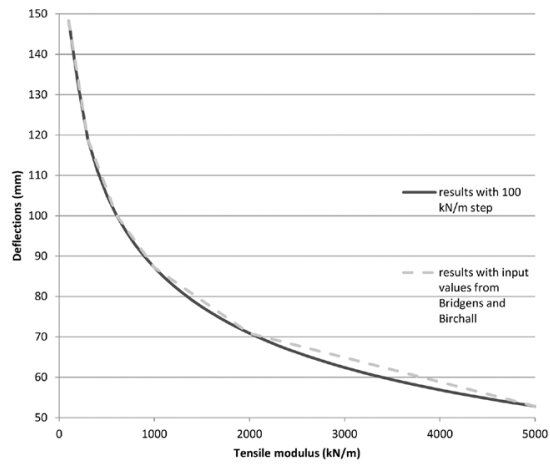

Figure 3 . Comparison of results from two input sets of data

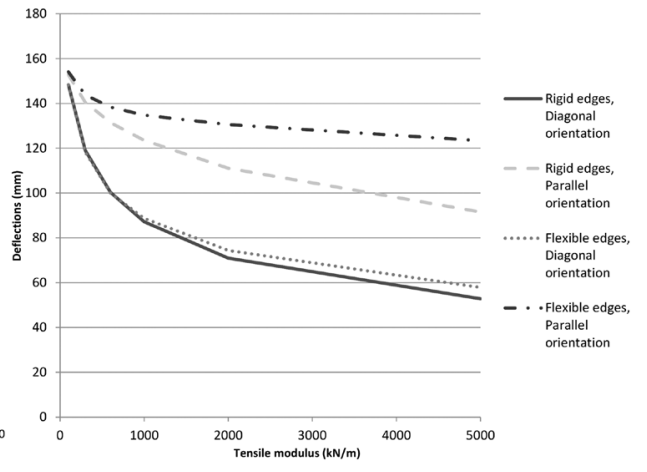

Figure 4. Deflections of four analyzed models under $1 \mathrm{kN}$ point load 
Results presented in Figure 3 allow for comparison of accuracy between the two sets of input data. It is obvious that the results obtained using 50 values of tensile modulus will give more accurate estimation for the values in-between the analysed ones. However, the six values used by Bridgens and Birchall give a very good approximation of the connection between the tensile modulus and maximal deflections under point load. Somewhat larger deviation is noticed for values between 3000 and $4000 \mathrm{kN} / \mathrm{m}$. Having in mind that there are about eight times less input values, and that this results in less computation time, less memory space and input data, it can be concluded that this set brings more benefits with satisfactory estimation accuracy for the values which are not analysed. The six selected values are wisely chosen to be denser at lower values of tensile modulus, since the changes of maximal deflections are larger in this region. Based on these conclusions, for the further investigation in this research, previously proposed values of 100, 300,600, 1000, 2000 and $5000 \mathrm{kN} / \mathrm{m}$ for tensile modulus of the membrane material are selected.

The next task of the research was to analyse all four different models for the effects of change of tensile modulus. Point load was applied in the centre of the membrane with the value of $1 \mathrm{kN}$. The results for maximum membrane deflections are shown in Figure 4. Model with rigid edges and diagonal orientation of the membrane material is marked with continuous line, model with rigid edges and parallel orientation with dashed line, model with flexible edges and diagonal orientation with dotted line and model with flexible edges and parallel orientation with dash-dot line.

Based on the results presented in Figure 4, it can be observed that the relation between the tensile modulus and deflections is highly nonlinear. The increase of the value of tensile modulus results in the decrease of the deflections under point load. Bridgens and Birchall got similar results for wind uplift area load of $1 \mathrm{kN} / \mathrm{m}^{2}$. There are big differences in deflections under point load of the four analysed models. For the lowest value of the tensile modulus these differences are not significant, but they increase as the value of the tensile modulus increases. The model with flexible edges and parallel orientation of the material has the largest deflections, and is followed by the models with rigid edges and parallel material orientation. The models with rigid edges and diagonal material orientation and the model with flexible edges and diagonal material orientation have similar deflection results, which are significantly lower than the other two models. It can be concluded that the orientation of the material has higher impact on membrane deflections than the type of the membrane edges, under analysed values of the tensile modulus of the material. The results also show that diagonal positioning of the material is more beneficial deflection-wise, and 


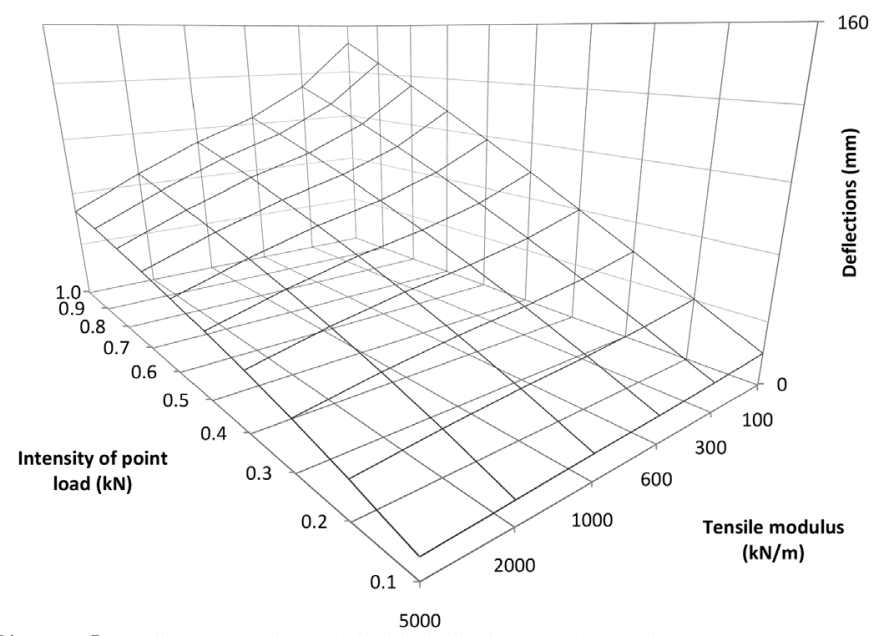

Figure 5. Deflections of the model with rigid edges and diagonal orientation

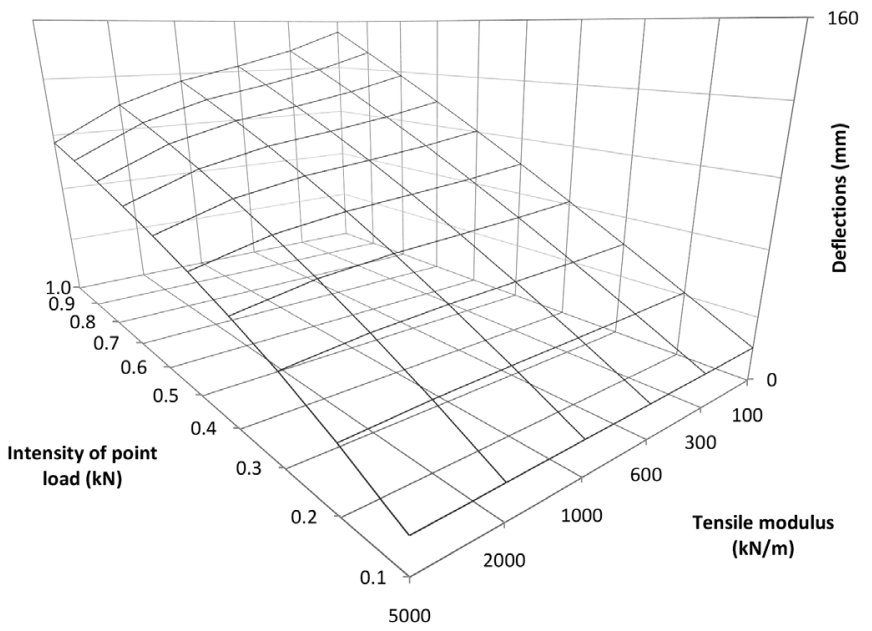

Figure 6 . Deflections of the model with rigid edges and parallel orientation

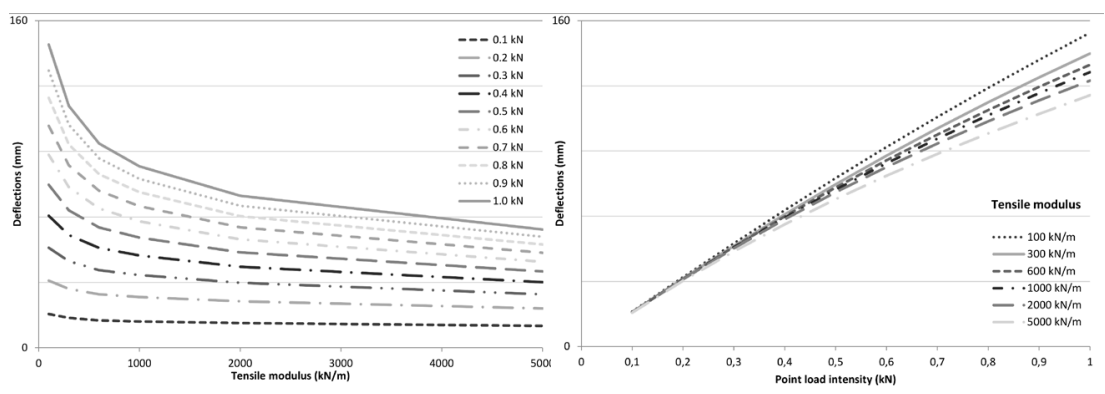

Figure 7 . Deflections of the model with flexible edges and diagonal orientation

Figure 8. Deflections of the model with flexible edges and parallel orientation 
it can therefore be recommended for use in situations where deflections are too large. Finally, when conducting tests of the membrane material in order to determine the tensile modulus, special attention should be given to the models with lower tensile modulus, since small mistakes in the value of the tensile modulus will result in larger mistakes of membrane deflections during the structural analysis.

In the last part of the presented research, four models are loaded with point loads of different intensities. The intensity of the point load was varied from 0.1 to 1.0 $\mathrm{kN}$ with $0.1 \mathrm{kN}$ step. The position of the point load was unchanged. Parallel to this, the tensile modulus of the material was varied on each model. Values of $100,300,600,1000,2000$ and $5000 \mathrm{kN} / \mathrm{m}$ were used. By combining these two parametres 240 different sets were defined on the four analysed models. Each change of the tensile modulus value was followed by the form-finding process before the application of loads. Loads were applied separately and the maximal deflections were recorded. The results are presented in Figures 5, 6, 7 and 8. Each figure presents 60 results for different models. Figure 5 presents the deflection results of the model with rigid edges and diagonal material orientation, Figure 6 for model with rigid edges and parallel material orientation, Figure 7 for model with flexible edges and diagonal material orientation, and Figure 8 for model with flexible edges and parallel material orientation.

The analysis of the results presented in Figure 5 gave several conclusions. The relation between the intensity of point load and deflections under different tensile modulus values is nonlinear. Nonlinearity increases with the increase of tensile modulus. With the increase of point load intensity the deflections increase. Variation of the point load intensity does not change the behavior of the structure under different tensile modulus values. Thus, the shape of the graph lines is similar under different values of the point load, and only the values of deflections change. The results show excellent consistency. The results from other models presented in Figures 6,7 and 8 do not show any deviations and confirm the drawn conclusions. All these figures show the same type of data for different models, but results in Figures 7 and 8 are presented with different diagram types in order to corroborate the conclusions. In Figure 7 the same relation between results under different point load intensities can be noticed. Figure 8 shows the nonlinear relation between point load intensity and deflections at analysed tensile modulus values. 


\section{CONCLUSION}

The aim of this research was to investigate the relation between the tensile modulus of the membrane material and deflections under point load. Four numerical models differing in material orientation and type of membrane edges were created in software Sofistik 2016. These models were loaded with point loads positioned in the center of the membrane. The value of the tensile modulus of the material used on the models was varied. Simultaneously, the intensity of the point load was also varied. The changes in membrane deflections were monitored. Based on the results, the conclusions about the influence of tensile modulus on deflections were drawn.

In the first phase of the research presented in this paper, the adequate values of the tensile modulus of the membrane material were selected for further research. Then, these values were used in combination with different material orientations and different types of membrane edges. Four defined models were used to analyse 240 different sets of parameters. The results showed that the relation between the tensile modulus of the material and deflections under point load is nonlinear. The deflections decrease as the tensile modulus increases. As a consequence, more precise determination of tensile modulus is needed for the materials with its lower values. Diagonal orientation of the membrane material, as well as rigid membrane edges will result in lower deflections under analysed tensile modulus values. The intensity of the applied point load does not change the behaviour of the structure with respect to the influence of the tensile modulus on membrane deflection, but only affects the magnitude of deflections. The results of this research helped to establish a connection between the value of the tensile modulus of the membrane material and deflections under point load. Three other parametres were varied to widen the volume of the research. As the final conclusion of the research, it can be stated that the increase of the tensile modulus of the membrane material reduces deflections under point load, and therefore the selection of materials with higher tensile modulus is an efficient way of preventing large deflections of membrane structures. The benefits of application of this method can be further improved by the right selection of the material orientation and the type of membrane edges. 
NOTES
Jorg Uhlemann, "Elastic Constants of Architectural Fabrics for Design Purposes," (PhD Thesis, Duisburg: Universität Duisburg-Essen, 2016).

Natalie Stranghoner, Jorg Uhlemann, Faruk Bilginoglu, Kai-Uwe Bletzinger, Heidrun BognerBalz, Evi Corne, Nick Gibson, et al. Prospect for European Guidance for the Structural Design of Tensile Membrane Structures (Luxembourg: European Commission, Joint Research Centre, 2016).

Brian Forster and Marijke Mollaert. European Design Guide for Tensile Surface Structures (Brussels: TensiNet, 2004).

Stranghoner, Uhlemann et al. Prospect for European Guidance for the Structural Design of Tensile Membrane Structures.

Ben Bridgens, Peter Gosling, G-T Jou and X-Y Hsu, "Inter-Laboratory Comparison of Biaxial Tests for Architectural Textiles," The Journal of the Textile Institute 103 (2012): 706-718; Jorg Uhlemann, Natalie Stranghoner and Klaus Saxe, "Stiffness Parameters for Architectural Fabrics: An Analysis of Two Determination Procedures," Structural Engineering International 25, No. 1 (2015): 9-19; Jorg Uhlemann, Natalie Stranghoner and Klaus Saxe, "Tensile Structures: Investigation into the Determination of Elastic Constants of Fabrics," Journal of the International Association for Shell and Spatial Structures 58 (2015): 25-35.

Andrzej Ambroziak, "Analysis of Non-Linear Elastic Material Properties of PVC-Coated Panama Fabric," Task Quarterly 9, No 2 (2005): 167-178; Andrzej Ambroziak, "Mechanical Properties of Precontraint 1202S Coated Fabric Under Biaxial Tensile Test with Different Load Ratios," Construction and Building Materials 80, (2015): 210-224; Andrzej Ambroziak and Pawel Klosowski, "Mechanical Properties for Preliminary Design of Structures Made from PVC Coated Fabric," Construction and Building Materials 50, (2014): 74-81; Jorg Uhlemann, Natalie Stranghoner and Klaus Saxe, "Comparison of Stiffness Properties of Common Coated Fabrics," Steel Construction 8 (2015): 222-229; Yingying Zhang, Qilin Zhang, Ke Lei and Bei-Lei Kuai, "Experimental Analysis of Tensile Behaviors of Polytetrafluoroethilene-Coated Fabrics Subjected to Monotonous and Cyclic Loading," Textile Research Journal 84 (2014): 231-245; Yingying Zhang, Qilin Zhang, Zonglin Yang, Lu Chen and Yuan Cao, "LoadDependent Mechanical Behavior of Membrane Materials and its Effect on the Static Behaviors of Membrane Structures," Journal of Materials in Civil Engineering 27, (2015): 1-11; Yingying Zhang, Qilin Zhang, Chuanzhi Zhou and Ying Zhou, "Mechanical Properties of PTFE Coated Fabrics," Journal of Reinforced Plastics and Composites 29 (2010): 3624-3630.

Ben Bridgens and Peter Gosling, "Round Robin Exercise 2: Interpretation of Biaxial and Shear Test Data," TensiNews 28 (2015): 16-17.

Ben Bridgens and Matthew Birchall, "Form and Function: The Significance of Material Properties in the Design of Tensile Fabric Structures," Engineering Structures 44, (2012): 1-12.

Sofistik. ASE General Static Analysis of Finite Element Structures (Oberschleissheim: SOFiSTiK AG, 2015).

Vatyu Tanev, “Текстилни мембранни конструкции сс стоманен опорен контур”, (PhD Thesis, Sofia: University of Architecture, Civil Engineering and Geodesy, 2005). 
Ambroziak, Andrzej. “Analysis of Non-Linear Elastic Material Properties of PVC-Coated Panama Fabric.” Task Quarterly 9, No 2 (2005): 167-178.

Ambroziak, Andrzej. "Mechanical Properties of Precontraint 1202S Coated Fabric Under Biaxial Tensile Test with Different Load Ratios." Construction and Building Materials 80 (2015): 210-224.

Ambroziak, Andrzej and Pawel Klosowski. "Mechanical Properties for Preliminary Design of Structures Made from PVC Coated Fabric." Construction and Building Materials 50 (2014): 74-81.

ASCE. 2010. Tensile Membrane Structures. ASCE Standard, ASCE/SEI 55-10. Reston: ASCE, SEI.

Bridgens, Ben and Matthew Birchall. "Form and Function: The Significance of Material Properties in the Design of Tensile Fabric Structures." Engineering Structures 44 (2012): 1-12.

Bridgens Ben and Peter Gosling. "Round Robin Exercise 2: Interpretation of Biaxial and Shear Test Data.” TensiNews 28 (2015): 16-17.

Bridgens, Ben, Peter Gosling, G-T Jou and X-Y Hsu. "Inter-Laboratory Comparison of Biaxial Tests for Architectural Textiles.” The Journal of the Textile Institute 103 (2012): 706-718.

Forster, Brian and Marijke Mollaert. European Design Guide for Tensile Surface Structures. Brussels: TensiNet, 2004.

Milošević, Vuk. "Dependence of Membrane Deflection on the Position and Intensity of Point Loads." Structural Engineering International 25, No. 1 (2015): 20-25.

Milošević, Vuk, Biserka Marković and Dragoslav Stojić. "Effects of Different Prestress Intensities on the Displacement of Membrane Structures under Point Loads." Facta Universitatis series: Architecture and Civil Engineering 14, No. 3 (2016): 311-318.

Milošević, Vuk, Biserka Marković and Dragoslav Stojić. "Effects of Point Loads on Membrane Structures." Građevinar 69, in press, https://doi.org/10.14256/JCE.1670.2016

MSAJ. 1995. MSAJ/M-02-1995. Testing Method for Elastic Constants of Membrane Materials. Membrane Structures Association of Japan, from (Uhlemann 2016)

Sofistik. ASE General Static Analysis of Finite Element Structures. Oberschleissheim: SOFiSTiK $\mathrm{AG}, 2015$.

Stranghoner, Natalie, Jorg Uhlemann, Faruk Bilginoglu, Kai-Uwe Bletzinger, Heidrun BognerBalz, Evi Corne, Nick Gibson, et al. Prospect for European Guidance for the Structural Design of Tensile Membrane Structures. Luxembourg: European Commission, Joint Research Centre, 2016.

Tanev, Vatyu. Текстилни мембранни конструкиии сс стоманен опорен контур. $\mathrm{PhD}$ Thesis, Sofia: University of Architecture, Civil Engineering and Geodesy, 2005.

Uhlemann, Jorg. Elastic Constants of Architectural Fabrics for Design Purposes. PhD Thesis, Duisburg: Universität Duisburg-Essen, 2016.

Uhlemann, Jorg, Natalie Stranghoner and Klaus Saxe. "Comparison of Stiffness Properties of Common Coated Fabrics.” Steel Construction 8 (2015): 222-229.

Uhlemann, Jorg, Natalie Stranghoner and Klaus Saxe. "Stiffness Parameters for Architectural Fabrics: An Analysis of Two Determination Procedures." Structural Engineering International 25, No. 1 (2015): 9-19.

Uhlemann, Jorg, Natalie Stranghoner and Klaus Saxe. "Tensile Structures: Investigation into the Determination of Elastic Constants of Fabrics." Journal of the International Association for Shell and Spatial Structures 58 (2015): 25-35. 
Zhang, Yingying, Qilin Zhang, Ke Lei and Bei-Lei Kuai. "Experimental Analysis of Tensile Behaviors of Polytetrafluoroethilene-Coated Fabrics Subjected to Monotonous and Cyclic Loading." Textile Research Journal 84 (2014): 231-245.

Zhang, Yingying, Qilin Zhang, Zonglin Yang, Lu Chen and Yuan Cao. "Load-Dependent Mechanical Behavior of Membrane Materials and its Effect on the Static Behaviors of Membrane Structures.” Journal of Materials in Civil Engineering 27 (2015): 1-11.

Zhang, Yingying, Qilin Zhang, Chuanzhi Zhou, and Ying Zhou. "Mechanical Properties of PTFE Coated Fabrics." Journal of Reinforced Plastics and Composites 29 (2010): 3624-3630. 


\section{RAČUNARSKO PROJEKTOVANJE I ANALIZA TENSEGRITI STRUKTURA Jelene Milošević, Đorđe Nedeljković}

Rad prikazuje primenu računarskih alata u projektovanju i analizi integralno zategnutih (tensegriti) struktura. Proces oblikovanja ovog specifičnog tipa prostornih struktura određen je razmatranjem interelacije forma-struktura. Iz tog razloga, održivi pristup njihovom projektovanu podrazumeva primenu alata koji mogu da prikazuju geometriju i simuliraju fizičko ponašanje ovih struktura. U skladu sa tim, kroz istraživanje smo testirali primenu računarskog alata Fasttens u projektovanju tensegriti struktura. Fasttens program je zasnovan na računarskoj procedure za nelinearnu analizu tensegriti sistema koju je originalno razvio dr Miodrag Nestorović. Kako bi pokrenuli originalni program napisan u Turbo Paskalu, izvršili smo emulaciju, korišćenjem emulatora DOSBox. Primena alata testiran je u projektovanju konkretne tensegriti strukture. Prikazani dizajn i numerički eksperiment potvrdio je efikasnost predloženog pristupa.

KLJUČNE REČI: TENSEGRITI STRUKTURE, PROJEKTOVANJE STRUKTURA, RAČUNARSKO PROJEKTOVANJE, RAČUNARSKA ANALIZA, FASTTENS

UTICAJ MODULA ELASTIČNOSTI MEMBRANSKOG MATERIJALA NA UGIBE MEMBRANE POD DEJSTVOM KONCENTRISANE SILE

\section{Vuk Milošević, Biserka Marković}

Svojstva membranskih konstrukcija uglavnom su definisana karakteristikama membranskog materijala. Jedna od najvažnijih karakteristika membranskog materijala je modul elastičnosti. U ovom radu prikazano je istraživanje odnosa modula elastičnosti membranskog materijala i ugiba membrane pri dejstvu koncentrisane sile. Ispitivanje je izvršeno na numeričkim modelima u specijalizovanom softveru. Vrednost modula elastičnosti je varirana, a promene ugiba membrane su praćene. Takođe, menjana je i orijentacija membranskog materijala i tip ivičnih oslonaca. Dobijeni rezultati pomogli su u razumevanju uticaja modula elastičnosti membranskog materijala na ugibe membrane pod dejstvom koncentrisane sile.

KLJUČNE REČI: MEMBRANSKE KONSTRUKCIJE, ZATEGNUTE KONSTRUKCIJE, MODUL ELASTIČNOSTI, UGIBI, KONCENTRISANA SILA 